\title{
JONNESCO: One Century of Thoracic Spinal Anesthesia History
}

[Rev Bras Anestesiol 2010;60(4): 347-348] OElsevier Editora Ltda.

To the Editor

I have just received the most recent issue of our Journal (RBA, July/August 2010) and read the Editorial published at the same issue by Dr. Luiz Eduardo Imbelloni ${ }^{1}$, a colleague well known for his works and interest in regional anesthesia.

In his text, he mentions the method of thoracic spinal anesthesia through puncture carried out in any intervertebral space, proposed by Dr. T. Jonnesco ${ }^{2}$ in his article published in 1909 at the British Medical Journal, recommending this technique for subarachnoid blocks carried out in all column segments from cervical to lumbar with greater emphasis on the access through the thoracic region.

Since an "Editorial" by definition expresses the concordance of opinions of those in charge of a journal, some considerations are necessary in these circumstances.

Jonnesco was a very controversial figure and his results were neither convincing nor confirmed. It is enough to state the comment signed "A.N" at the California State Journal of Medicine, from $1911^{3}$, where deaths are cited and the aforementioned author described as a "true fraud" that used the "lay press to self-promotion". Similarly, the same thing can be observed in the article by McGavin L. at the British Medical Journal from $1910^{4}$ where 18 cases are presented and a comment made that in a demonstration of 3 anesthetic procedures carried out by Jonnesco, only one patient obtained satisfactory results as the others required the use of general anesthesia for the programmed surgical procedure to be carried out.

Carlos Parsloe in an excellent review presented at the International College Series ${ }^{5}$ made an analysis of the "total spinal anesthesia", according to the description of Jonnesco in 398 surgical procedures, and made considerations on the latter and the time when it was presented. Even the book that Jonnesco published in 1919, Rachianestesie Generale 6 , could not prevent the abandonment, within a very short time, of such a risky and low-safety procedure ${ }^{7,8}$.

The last reference we saw on this subject, spinal blocks carried out at the thoracic level, was the one by van Zundert ${ }^{9}$ who published a total of 20 cases and recommended caution when performing this type of anesthesia, as from a statistical point of view the report of 20 blocks without sequelae is not a significant one. A much larger number would be necessary of one to three thousand procedures carried out successfully and without sequelae to suggest that the method could be adopted safely. Upper back blockades, both spinal and epidural, mainly those carried out at the thoracic level have a high potential and actual risk of causing severe neurological lesions, such as paraplegia or paresis due to the anatomy of the vertebral column at this region. The fact that the spinal cord tissue is insensitive to needle penetration during an accidental puncture during any inadvertent introduction of an intramedullary catheter or fluid injection greatly increases the probability of an accident such as that. Only the nervous roots show a reaction when affected, as paresthesia or even pain 10-40,42-44.

In addition to the possibility of direct trauma caused by the needle, there is a risk of spinal or epidural hematomas, causing paralysis or similar lesions ${ }^{41}$. In other rare circumstances, neurologic sequelae can follow a subarachnoid block, for reasons that are not always clear ${ }^{44-48}$.

One must not forget the possible diffusion of the anesthetic agent through the spinal canal causing sudden and severe hypotension in addition to respiratory distress or apnea $10,11,19,26,39,42,46,47,49-53$.

Thus, considering all that has been shown and described in the literature we believe that the spinal blocks carried out in the cervical or thoracic segments must be completely dismissed in our daily routine and only remembered as a frustrated and risky attempt, of which outcomes were not the expected and whose use has been abandoned for more than 70 years.

The only justification to accept a subarachnoid block at those levels in the present would be a glycerin-phenol injection (Maher RM - Results of subarachnoid phenol blocks. In: Relief of Intractable Pain. Edited by M. Swerdlow. Amsterdam, Elsevier, 1983, page 192) or other neurolytic agent such as alcohol (Dogliotti) for the treatment of incoercible pain caused by advanced neoplastic processes. I did a fellowship in 1962 under Maher's supervision in England and had the opportunity to carry out some intradural injections under his supervision with acceptable results in $70 \%$ of the 8 patients thus treated, without paraplegia or other severe neurologic sequelae. Small doses and slow injections with the patient kept in lateral decubitus until the block fixation was achieved were part of the technique. Some other cases were treated at our Pain Clinic in the Santa Casa de Santos and also in the Hospital Universitário de Caracas where I was invited to teach by WHO during the 1970s with a similar percentage of success.

Its indications are restricted, but can bring pain relief to individuals that are suffering and have a short life expectancy. In this situation, we believe that the occurrence of neurological sequelae can be accepted by the patient. 
In brief, it is our opinion that Jonnesco and his technique must remain as a remembrance of a bygone era. Reading the works cited in the reference list, we believe that this method should only be employed at present if the anesthesiologist could answer "yes" to the following question: "Would you allow the use of these blocks in yourself, your wife, son, daughter or siblings?" 53-56.

Moreover, the current high number of malpractice suits against physicians, which have been increasing progressively among us who live in a country where there are 1,300 Law Schools, makes the risks unacceptable for the professional involved with it 53 .

Imagine making the patient sign an informed consent form for this type of anesthesia, which would mandatorily contain all the accident hypotheses and possible adverse events, mentioning the permanent neurological sequelae that could result from such action!
Considering what is currently known, we believe the risks are not worth it. We have safer general anesthesia methods that can be used in all cases for which this "segmental spinal block" was considered an indication in old times, such as the 1920 s and 1930s, which represents the "Middle Ages" of modern anesthesiology.

The fundamental principle of Medicine, "Primum non nocere", must be always kept in mind before performing any procedure capable of causing potential damage or irreversible sequelae to our patients ${ }^{7}$.

Prof. Armando Fortuna, TSA, DA (Din.), DA (England), FACA (USA)

Faculdade de Ciências Médicas de Santos (Retired)

Lawyer OABSP

Founder and Ex-Director of integrated CETs of Santa Casa and of Beneficencia Portuguesa de Santos 


\section{REFERÊNCIAS / REFERENCES}

01. Imbelloni LE - Jonnesco: one century of thoracic spinal anesthesia history. Rev Bras Anestesiol, 2010;60:347-348.

02. Jonnesco T - General spinal anesthesia. Br Med J, 1909;2:1396-1401

03. A.N. - Jonnesco and spinal anesthesia. California State J Med, 1911;9:401-402

04. McGavin $L-$ Remarks on eighteen cases of spinal analgesia by the stovaine-strychnine methods of Jonnesco, including six cases of high dorsal puncture. Brit Med J, 1910;2:733-726.

05. Parsloe C - Deliberate total anesthesia: proponents and techniques (1901-1948), International Congress Series 1242, 2002; 169-172.

06. Jonnesco T - La Rachianestesie Generale. Paris, Masson, 1919.

07. Fortuna A - Primum non nocere. A forgotten principle? Cyber Congress, Mexico, 2008.

08. Bedforth NM, Hardman JG - The hidden cost of neuroaxial anesthesia? Anaesthesia, 2010;65:437-439.

09. van Zundert AAJ, Stultiens G, Jakimowicz JJ et al. - Laparoscopic cholecystectomy under segmental thoracic spinal anaesthesia: a feasibility study. Br J Anaesth, 2007:98:682-686.

10. Fortuna A, Fortuna AO - Complicações e acidentes em bloqueios regionais (anestesias raquídea e peridural). Rev Bras Cir, 1989;79:5-10.

11. Fortuna A-Bloqueios anestésicos. Rev Bras Anestesiol, 1963;13:227262;326-351

12. Fortuna A - Neuropathies after neuraxial anaesthesia. Anestesia Rianimazioni, 2003;1(1).

13. Carpenter RL, Caplan RA, Brown DL et al. - Incidence and risk factors for side effects of spinal anesthesia. Anesthesiology, 1992:76:906-916.

14. Kao MC, Tsai SK, Tsou MY et al. - Paraplegia after delayed detection of inadvertent spinal injury during thoracic epidural catheterization in an anesthetized elderly patient. Anesth Analg, 2004;99:580-583.

15. Poulder D, Elliot $S$ - An awake patient may not detect spinal cord puncture. Anaesthesia, 2000;55:194.

16. Horlocker TT, Wedel DJ - Neurologic complications of spinal and epidural anesthesia. Reg Anesth Pain Med, 2000;25:83-98.

17. Aldrete JA, Ferrari $\mathrm{H}$ - Mielopathy with syringomyelia following thoracic epidural anesthesia. Anaesth Intensive Care, 2004;32:100-103.
18. Auroy $Y$, Narchi $P$, Messiah A et al. - Serious complications related to regional anesthesia: results of a prospective survey in France. Anesthesiology, 1997;87:479-486

19. Aromaa U, Lahdensuu M, Cozanitis DA - Severe complications associated with epidural and spinal anaesthesias in Finland 1987-1993. A study based on patient insurance claims. Acta Anaesthesiol Scand, 1997;41:445-452.

20. Kasai T, Yaegashi K, Hirose $\mathrm{M}$ et al. - Spinal cord injury in a child caused by an accidental dural puncture with a single-shot thoracic epidural needle. Anesth Analg, 2003;96:65-67.

21. Hodgson PS, Neal JM, Pollock JE et al. - The neurotoxicity of drugs given intrathecally (spinal). Anesth Analg, 1999;88:797-809.

22. Aldrete JA - Arachnoiditis: the Silent Epidemic. $1^{\circ}$ Ed, Mexico, Future Med, 2000

23. Carli $\mathrm{F}$, Klubien $\mathrm{K}$ - Thoracic epidurals: is analgesia all we want? Can J Anaesth, 1999;46:409-414.

24. Bromage RP - Neurological complications of subarachnoid and epidural anaesthesia. Acta Anaesthesiol Scand, 1997;41:439-444.

25. Renck $\mathrm{H}-$ Neurological complications of central nerve blocks. Acta Anaesthesiol Scand, 1995;39: 859-868.

26. Fortuna A, Fortuna AO - Raquianestesia - Posição Atual, em: Silva Neto JD, Vale NB - Controvérsias em Anestesiologia. Rio de Janeiro, Atheneu, 1990;11-17

27. Simpson R - Neuroaxial catastrophes (chemical, infective and ischemic), em: World Congress of Anesthesia, 7., Hamburg. Proceedings... Excerpta Medica, 1981;960-962.

28. Usubiaga JE, Usubiaga LE - Classificações das síndromes neurológicas pós-anestesia raquídea e peridural. Rev Bras Anestesiol, 1969;19:518-536.

29. Reynolds F - Damage to the conus medullaris following spinal anaesthesia. Anaesthesia, 2001;56:238-247.

30. Kane RE - Neurological deficits following epidural or spinal anesthesia. Anesth Analg, 1981; 60:150-161.

31. Fortuna A, Pradier P, Almeida MR - Severe neurological sequelae after spinal and epidural blocks. Consideration of 32 cases reported in Nicaragua, em: World Congress of Anesthesiology, 9, 1988. Abstracts... Washington, USA. 1988; v.2: AO 899.

32. Reis MP, Lima ICPR, Jung Li et al. - Paraplegias após bloqueios anestésicos. Rev Bras Anestesiol, 1993;43(Supl 17):CBA 068. 
33. Mayal MF, Calder I - Spinal cord injury following an attempted thoracic epidural. Anaesthesia, 1999;54:990-994.

34. Trindade RMC, Leal JH, Castro RFD - Complicação neurológica após anestesia regional. Rev Bras Anestesiol, 1994;44(Supl 18):CBA 016

35. Hodges SD, Castleberg RL, Millet T et al. - Cervical epidural steroid injection with intrinsic spinal cord damage. Two cases reports. Spine, 1998:23:2137-2142.

36. Ben-David B, Rawa R - Complications of neuroaxial blockade. Anesthesiol Clin North Am; 2002;20:669-693.

37. Dahlgren N, Törnebrandt K - Neurological complications after anesthesia. A follow-up of 18.000 spinal and epidural anaesthetics performed over three years. Acta Anaesthesiol Scand, 1995;39:872-880.

38. Brull R, McCartney CJL, Chan VWS et al. - Neurological complications after regional anesthesia: contemporary estimates of risk. Anesth Analg, 2007;104:965-974.

39. Lovstad RZ, Granhus G, Hetland S - Bradycardia and asystolic cardiac arrest during spinal anaesthesia: a report of five cases. Acta Anaesthesiol Scand, 2000;44:48-52.

40. Seze MP, Sztark F, Janvier G et al. - Severe and long-lasting complications of the nerve root and spinal cord after central neuroaxial blockade. Anesth Analg, 2007;104:975-979.

41. Newrick $P$, Read $D$ - Subdural haematoma as a complication of spinal anaesthetic. Br Med J (Clin Res Ed), 1982;285: 341-342.

42. Benhamou D, Auroy $Y$ - Overview of regional anesthesia complications, em: Neal JM, Rathmell JP - Complications in Regional Anesthesia and Pain Medicine. Philadelphia, Saunders Elsevier, 2008:7-16.

43. Absalom AR, Martinelli G, Scott NB - Spinal cord injury caused by direct damage by local anaesthetic infiltration needle. $\mathrm{Br} \mathrm{J}$ Anaesth, 2001;87:512-515.
44. Munnur U, Suresh MS - Backache, headache, and neurologic deficit after regional anesthesia. Anesthesiol Clin North Am, 2003;21:71-86.

45. Vandam LD, Dripps RD - Long-term follow-up of patients who received 10098 spinal anesthetics: syndrome of decreased intra-cranial pressure (headache and ocular and auditory difficulties). J Am Med Assoc, 1956;161:586-591.

46. Whizar LV, Carrada PS - Anestesia subaracnóidea. Cien años después. Rev Mex Anest 1999; 22:1-4.

47. Auroy $Y$, Benhamou D, Bargues $L$ et al. - Major complications of regional anesthesia in France: The SOS Regional Anesthesia Hotline Service. Anesthesiology, 2002;97:1274-1280.

48. Fortuna $A-$ Erros fatais e indefensáveis em anestesia regional. Anest Rev, 2007;57(1):25.

49. Caplan RA, Ward RJ, Posner $\mathrm{K}$ et al. - Unexpected cardiac arrest during spinal anesthesia: a closed claims analysis of predisposing factors. Anesthesiology, 1988;68:5-11.

50. Fortuna A - Complicações em anestesias regionais. Rev Bras Anestesiol, 1988;38(supl 10):CBA 50

51. Fortuna A - Toxicidade dos Anestésicos Locais, em: Congresso Brasileiro de Anestesiologia, 52., 2005, Goiânia .

52. Wils $\mathrm{JH}$ - Rapid onset of massive subdural anesthesia. Reg Anesth Pain Med, 2005;30:299-302.

53. Fortuna $A$ - Anestesia peridural torácica para cirurgia em posição sentada/peridural torácica para cirurgia de mama ou abdômen com sedação venosa. Rev Bras Anestesiol, 1989;39:401-408.

54. Low J, Johnston N, Morris C - Epidural analgesia: first do no harm. Anaesthesia 2008;63:1-3.

55. Ostwald K - Medico legal issues in regional anesthesia, ASRA NEWS, 1990 Feb;2-3

56. Szypula K, Ashpole KJ, Bogod D et al. - Litigation related to regional anaesthesia: an analysis of claims against the NHS in England 19952007. Anaesthesia, 2010;65:443-452. 